\title{
ABREVIASI PADA BERITA DALAM SURAT KABAR JAWA POS
}

\author{
Muhammad Said Adnan \\ Pendidikan Bahasa dan Sastra Indonesia, Universitas Muhammadiyah Jember \\ Email: s.adnan0901@gmail.com
}

DOI: http://dx.doi.org/10.32528/bb.v4i2.2560

Diterima: 18 Juli 2018

Diterbitkan: 30 Oktober 2019

\begin{abstract}
ABSTRAK
Di dalam sebuah media masa termasuk surat kabar, banyak ditemui ada nya bentuk abreviasi; namun masih banyak orang yang tidak memahami baik dari segi bentuk maupun proses pembentukannya. Penelitian ini bertujuan untuk mendeskripsikan bentuk dan proses pembentukan istilah abreviasi yang terdapat di surat kabar Jawa Pos terbitan 20 Oktober 2018. Jenis penelitian ini adalah deskriptif kualitatif. Data dalam penelitian ini berupa istilah abreviasi yang meliputi singkatan, akronim, penggalan, kontraksi dan lambang huruf. Sumber data dalam penelitian ini diperoleh dari surat kabar Jawa Pos terbitan20 Oktober 2018. Teknik pengumpulan data yang digunakan dalam penelitian ini yaitu teknik dokumentasi. Instrumen dalam penelitian ini yaitu peneliti sendiri selaku instrumen utama. Metode dan teknik analisis data yaitu dengan teknik Pilah Unsur Penentu (PUP). Selanjutnya, teknik keabsahan temuan peneliti menggunakan ketekunan pengamatan. Hasil penelitian yang diperoleh oleh peneliti adalah terdapat istilah abreviasi dalam surat kabar Jawa Pos terbitan terbitan 20 Oktober 2018 antara lain yaitu singkatan, akronim, penggalan, kontraksi dan lambang huruf. Singkatan sering kali kita jumpai khususnya saat membaca surat kabar.
\end{abstract}

Kata kunci: abreviasi, berita, surat kabar

\section{ABSTRACT}

In mass media including newspapers, abbreviations are commonly found. However, not many of us understand in terms of its form as well as the formation process. This study aims to describe the type and formation process of abbreviation in Jawa Pos newspaper published on October 20th, 2018. This type of research is qualitative descriptive. The data of this research are in the form of abbreviation terms which include abbreviations, acronyms, fragments, contractions and letter symbols. The data source in this study was obtained from the Jawa Pos newspaper published on Oktober 20th, 2018. Data collection technique used in this study is documentation techniques, while the instrument of the data collection is the researcher himself as the main instrument. The method and data analysis technique used is the Determine Element (PUP) technique. Then the validity technique of the findings of the researcher used tenacity observation. The results of the research obtained are that there is the showed the abbreviation in Jawa Pos newspaper published on October 20th, 2018, includes abbreviations, acronyms, fragments, contractions and letter symbols. Amongst, abbreviations are the most commonly found.

Keywords: abreviations, news, newspapers

\section{PENDAHULUAN}

Manusia merupakan makhluk sosial yang senantiasa berinteraksi dengan sesamanya. Interaksi antar sesama manusia dapat ditunjukkan melalui kegiatan berkomunikasi. Chaer (2006:1) menyatakan bahwa bahasa adalah sistem lambang berupa bunyi, bersifat arbitrer, digunakan oleh suatu masyarakat tutur untuk bekerja sama, berkomunikasi, dan mengidentifikasi diri. Berbahasa merupakan suatu kegiatan sehari-hari 
manusia untuk saling berkomunikasi, berinteraksi atau bersosialisasi. Bahasa yang digunakan sendiri terdiri dari bahasa lisan dan bahasa tulis. Berdasarkan penggunaannya, bahasa lisan dan bahasa tulis ada yang terbentuk praktis sehingga mempermudah kegiatan komunikasi. Kepraktisan penggunaan bahasa lisan dan bahasa tulis ditunjukkan dengan adanya penggunaan pemendekan atau yang disebut dengan istilah 'abreviasi'.

Abreviasi merupakan pemendekan yang diartikan sebagai suatu proses pemenggalan satu atau beberapa leksem atau kombinasi leksem sehingga jadilah bentuk baru yang berstatus kata. Sedangkan hasil dari prosesnya disebut kependekan. Abreviasi memiliki beberapa jenis diantaranya yaitu, singkatan, akronim, penggalan, kontraksi dan lambang huruf (Harimurti Kridalaksana 2009, hal 161). Pendapat tersebut sejalan dengan Mulyono (2013, hal. 147) yang menyatakan bahwa abreviasi merupakan suatu proses pemendekan yang hasilnya disebut kependekan. Selanjutnya, menurut Azmi, dkk (2018: 2) abreviasi dalam bahasa Indonesia muncul karena terdesak untuk berbahasa secara cepat dan praktis tanpa mempertimbangkan pembaca mengerti atau tidak mengenai penggunaan abreviasi baik dalam majalah, tabloid maupun surat kabar. Berdasarkan beberapa pendapat tersebut, dapat disimpulkan bahwa abreviasi merupakan salah satu cara proses pembentukan kata, dengan cara menyingkat kata menjadi huruf, bagian kata atau gabungan kata, sehingga terbentuk istilah baru yang berbentuk kata.

Saat ini, hampir seluruh bidang kehidupan manusia menggunakan abreviasi sebagai wujud kepraktisan dalam berbahasa. Sehingga dengan adanya abreviasi tersebut, berbagai istilah menjadi lebih efektif dan mudah untuk diingat. Selain itu abreviasi juga merupakan unsur bahasa yang sering digunakan dalam penulisan berita khususnya pada berita di dalam surat kabar. Menurut Budyatna (2009, hal 39) menyatakan bahwa berita merupakan laporan aktual tentang fakta-fakta dan opini yang menarik atau penting bagi sejumlah orang. Sedangkan menurut Sumadiria (2005, hal 64) berita merupakan laporan tentang fakta atau ide termassa, yang dapat menarik perhatian pembaca karena sesuatu yang luar biasa, penting, mencakup sisi human interest seperti humor, emosi dan ketegangan. Jadi, berita adalah informasi hangat tentang sesuatu yang terjadi dan disajikan melalui berbagai media seperti surat kabar, radio, televisi, dan lainnya yang bersifat media massa. Berita merupakan bahan utama dalam media massa, baik elektronik maupun cetak. Akan tetapi, fokus pada penelitian ini hanya salah satu jenis dari media cetak saja yakni surat kabar.

Surat kabar saat ini semakin berkembang, hal ini didorong oleh keinginan masyarakat yang semakin kritis dan butuh informasi, terlebih lagi berita dalam surat kabar adalah benar adanya atau dengan kata lain sesuai dengan fakta yang ada di lapangan dan dapat dipertanggungjawabkan. Menurut Djuroto (2002, hal 11) memberi pengertian bahwa surat kabar merupakan kumpulan dari berita, artikel, cerita, iklan dans sebagainya yang dicetak ke dalam lembaran kertas ukuran plano yang diterbitkan secara teratur dan bisa terbit setiap hari atau seminggu sekali. Surat kabar merupakan salah satu jenis media cetak yang menggunakan bahasa tulis sebagai medianya. Melalui surat kabar tersebut, masyarakat dapat mengetahui informasi terkini dan aktual dari berbagai kejadian dalam suatu masyarakat baik yang bersifat lokal maupun mancanegara.

Pada dasarnya, bahasa yang dimuat dalam surat kabar merupakan bahasa yang dapat dikonsumsi atau dipahami oleh seluruh kalangan masyarakat. Selain itu, seorang jurnalis harus menyajikan informasi sebanyak-banyaknya dalam waktu yang sangat singkat, sehingga penulisan surat kabar haruslah singkat, efektif dan hemat kata dalam menulis sebuah berita. Hal tersebut menyebabkan munculnya sebuah pemendekan yang dalam ilmu linguistik disebut dengan istilah 'abreviasi'. Abreviasi sendiri banyak terdapat pada media cetak khususnya surat kabar. Namun dalam penggunaannya, masih banyak orang yang tidak mengetahui bentuk-bentuk abreviasi maupun makna dari istilah tersebut khususnya saat membaca surat kabar. Sehingga hakikat berita sebagai penyampai pesan dan informasi tersebut kurang tersampaikan dengan baik, karena masih banyak kalangan masyarakat yang belum memahami istilah-istilah abreviasi yang digunakan dalam pemberitaan surat kabar.

Objek pada penelitian ini adalah surat kabar Jawa Pos. Pemilihan surat kabar Jawa Pos tersebut sebagai objek penelitian karena adanya kecenderungan penulis Jawa Pos banyak menggunakan istilah abreviasi. Sehingga surat kabar tersebut dapat diteliti khususnya mengenai abreviasi. Penggunaan abreviasi dimaksudkan untuk menyingkat tulisan, mengingat ruang baik dalam penulisan berita, iklan dan lain sebagainya dalam surat kabar cukup terbatas dan sedikit. Peneliti juga memfokuskan surat kabar yang akan diteliti yakni pada terbitan 20 Oktober 2018. Hal itu dikarenakan data yang ditemukan cukup banyak, sehingga peneliti hanya membatasi pada terbitan tersebut.

Adapun beberapa contoh dari kelima jenis abreviasi tersebut yang ada pada surat kabar Jawa 
Pos antara lain (1) singkatan yakni NKRI yang merupakan kependekan dari Negara Kesatuan Republik Indonesia; (2) akronim yakni BAN yang merupakan kependekan dari Badan Akreditasi Nasional; (3) penggalan yakni Bu yang merupakan kependekan dari kata Ibu; (4) kontraksi yakni takkan yang merupakan kependekan dari kata tidak akan; dan (5) lambang huruf yakni cm yang merupakan bentuk kependekan dari kata centimeter. Berdasarkan kelima jenis abreviasi tersebut, masing-masing memiliki perbedaan sesuai dengan pengertiannya. Jadi, dengan adanya istilah tersebut akan lebih efektif baik dalam segi penggunaan verbal maupun tulisan.

Penelitian serupa pernah dilakukan sebelumnya oleh Nofin Suhartanti (2016) dengan judul Abreviasi Bahasa Indonesia Dalam Majalah Tentara Nasional Indonesia (TNI) Angkatan Darat. Perbedaan penelitian ini dengan penelitian sebelumnya terletak pada objek yang dikaji dan fokus penelitiannya. Penelitian sebelumnya menggunakan majalah sebagai sumber data dan berfokus pada jenis-jenis abreviasi, proses pembentukan abreviasi dan pemanfaatan abreviasi tersebut bagi pembelajaran bahasa Indonesia di jenjang SMP. Sedangkan penelitian ini menggunakan surat kabar sebagai sumber data penelitian dan berfokus pada jenis-jenis abreviasi dan proses pembentukannya. Sehingga diharapkan akan ada banyak referensi khususnya yang menyangkut istilah abreviasi.

\section{METODE PENELITIAN}

Penelitian ini termasuk jenis penelitian kualitatif dengan metode deskriptif. Penelitian kualitatif adalah penelitian yang memanfaatkan cara penafsiran dengan menyajikannya dalam bentuk deskriptif. Menurut Sukmadinata (2010: 7273) menyatakan bahwa penelitian deskriptif merupakan suatu bentuk penelitian yang paling dasar yang ditujukan untuk mendeskripsikan atau menggambarkan fenomena-fenomena yang ada tanpa adanya manipulasi. Dengan demikian, maka penelitian ini akan mendeskripsikan bentuk-bentuk penggunaan abeviasi dalam surat kabar Jawa Pos terbitan 20 Oktober 2018 dengan disertakan proses pembentukan pada setiap abreviasi yang ditemukan dalam surat kabar Jawa Pos tersebut.

Data penelitian merupakan bahan yang diteliti dalam penelitian. Sehingga data dalam penelitian ini berupa istilah abreviasi yang meliputi singkatan, akronim, penggalan, kontraksi dan lambang huruf serta poses pembentukan abreviasi dalam surat kabar Jawa Pos terbitan 20 Oktober 2018. Sumber data dalam penelitian merupakan subjek dari mana data dapat diperoleh. Sehingga sumber data dalam penelitian ini diperoleh dari surat kabar Jawa Pos terbitan 20 Oktober 2018. Teknik pengumpulan data dalam penelitian ini adalahteknik simak bebas libat cakap dan teknik catat. Pada teknik simak bebas libat cakap, peneliti membaca dan menyimak koran dengan baik sampai menemukan data berupa abreviasi. Sedangkan teknik catat merupakan teknik lanjutan dari teknik sebelumnya yang digunakan untuk mencatat data yang telah diperoleh dan digolongkan sesuai dengan jenisnya.

Instrumen dalam penelitian ini yaitu peneliti sendiri selaku instrumen utama. Peneliti sebagai human instrument, berfungsi menetapkan fokus penelitian, memilih informan sebagai sumber data, melakukan pengumpulan data, menilai kualitas data, menafsirkan data dan membuat kesimpulan atas semuanya.

Metode dan teknik analisis data yang digunakan dalam penelitian ini adalah metode padan pragmatis dengan teknik Pilah Unsur Penentu (PUP). Sudaryanto (2015:18) menyatakan bahwa metode padan pragmatis merupakan metode yang menggunakan mitra tutur atau lawan tutur sebagai alat penentu. Sedangkan teknik Pilah Unsur Penentu (PUP) merupakan teknik yang digunakan untuk memilah-milah data atau tuturan yang mengandung pelanggaran prinsip kerja sama Grice beserta maksud pelanggarannya.

Selanjutnya, teknik keabsahan temuan peneliti menggunakan ketekunan pengamatan, dengan demikian proses analisis serta pemahaman terhadap data yang ditemukan benar-benar sesuai dengan data dalam surat kabar yang telah dicari oleh peneliti, sehingga data yang telah ditemukan peneliti dapat dipertanggung jawabkan secara ilmiah karena peneliti benar-benar melakukan pengecekan keabsahan data dengan baik.

\section{PEMBAHASAN}

a) Singkatan

Berdasarkan data yang ada, penggunaan singkatan dalam surat kabar Jawa Pos menempati jumlah terbanyak dibandingkan jenis abreviasi lainnya. Adapun beberapa data yang ditemukan antara lain.

\section{(1) $\mathrm{BPKH}(\mathrm{S} 1)$}

Menurut Waridah (2008 : 13) singkatan merupakan proses pemendekan dari beberapa huruf yang digabungkan menjadi dieja dan tidak diejakan. Berdasarkan data di atas, maka data (1) merupakan abreviasi jenis singkatan. Proses terbentuknya kata BPKH yaitu dikarenakan adanya pengekalan huruf pertama pada setiap komponen. Fonem $B$ dikekalkan dari komponen Badan, fonem $P$ dikekalkan dari komponen Pengelola, fonem $K$ dikekalkan dari komponen Keuangan dan fonem $H$ dikekalkan dari komponen Haji. 
BPKH merupakan suatu lembaga yang melakukan pengelolaan keuangan haji. Jadi, tugas dari BPKH itu sendiri yakni mengelola seluruh keuangan haji yang meliputi penerimaan, pengembangan, pengeluaran dan pertanggungjawaban atas keuangan haji di Indonesia, sehingga dengan adanya suatu lembaga tersebut, keuangan haji di Indonesia akan lebih terkontrol dan terkoordinir dengan baik.

Sesuai dengan teori yang dikemukakan Waridah, peneliti setuju dengan teori tesebut. Hal itu disebabkan singkatan merupakan proses pemendekan huruf yang digabung menjadi satu, namun tidak dapat dieja. Alasan penggunaan istilah abreviasi tersebut dikarenakan lebih efektif, baik dalam penggunaan secara lisan maupun tulisan, sehingga dengan adanya penyingkatan, istilah tersebut menjadi lebih hemat, dan apabila istilah tersebut tidak digunakan, maka akan membutuhkan ruang yang lebih dalam surat kabar itu sendiri, mengingat ruang dalam surat kabar terbatas. Namun, istilah abreviasi seperti BPKH tersebut kadangkala membuat orang menjadi bingung, khususnya bagi pembaca yang masih berumur belia. Hal itu dikarenakan istilah abreviasi tersebut kadangkala hanya mencantumkan istilahnya saja, tanpa mancantumkan arti yang sebenarnya, sehingga yang pada awalnya surat kabar tersebut menjadi media informasi, justru menjadikan sebagian dari pembacanya kurang memahami apa informasi yang disampaikan oleh surat kabar tersebut.

\section{(2) NKRI (S2)}

Menurut Waridah (2008: 13) singkatan merupakan proses pemendekan dari beberapa huruf yang digabungkan menjadi dieja dan tidak diejakan. Berdasarkan data di atas, maka data (1) merupakan abreviasi jenis singkatan. Proses terbentuknya kata NKRI yaitu dikarenakan adanya pengekalan huruf pertama pada setiap komponen. Fonem N dikekalkan dari komponen Negara, fonem $\mathrm{K}$ dikekalkan dari komponen Kesatuan, fonem $\mathrm{R}$ dikekalkan dari komponen Republik dan fonem I dikekalkan dari komponen Indonesia

NKRI adalah negara yang dibentuk berdasarkan semangat kebangsaan (nasionalisme), yaitu tekad warga negara Indonesia untuk membangun dan memajukan masa depan bangsa walaupun berbeda agama, ras, suku, budaya, serta adat istiadatnya, sehingga dengan adanya NKRI tersebut, negara menjadi tentram dan damai walaupu banyak perbedaan di dalamnya.

Sesuai dengan teori yang dikemukakan Waridah, peneliti setuju dengan teori tesebut. Hal itu disebabkan singkatan merupakan proses pemendekan huruf yang digabung menjadi satu, namun tidak dapat dieja. Alasan penggunaan istilah abreviasi jenis singkatan tersebut disebabkan lebih efektif, baik dalam penggunaan secara lisan maupun tulisan, sehingga dengan adanya penyingkatan, istilah tersebut menjadi lebih hemat, dan apabila istilah tersebut tidak digunakan, maka akan membutuhkan ruang yang lebih dalam surat kabar itu sendiri, mengingat ruang dalam surat kabar terbatas. Istilah tersebut juga umum digunakan oleh masyarakat di Indonesia.

b) Akronim

(1) Jamkesmas(A1)

Akronim merupakan suatu proses pemendekan kata yang berupa gabungan huruf awal gabungan suku kata ataupun gabungan huruf dan suku kata dari deret kata yang diperlakukan sebagai kata (Ernawati Waridah, 2008: 15).

Berdasarkan data di atas, maka data (1) merupakan abreviasi jenis akronim. Proses terbentuknya kata Jamkesmas yaitu dikarenakan adanya pengekalan tiga huruf pertama pada komponen pertama. Pengekalan tiga huruf pertama komponen kedua, dan pengekalan tiga huruf pertama komponen ketiga. Sehingga kata Jam dikekalkan dari kata Jaminan, kes dikekalkan dari kata kesehatan dan mas dikekalkan dari kata masyarakat.

Sesuai dengan teori dari Waridah, peneliti setuju dengan teori yang digunakan. Hal itu disebabkan akronim merupakan suatu bentuk kependekan dari gabungan huruf yang menjadi suatu kata yang dapat diejakan. Alasan penggunaan istilah abreviasi tersebut dikarenakan lebih efektif, baik dalam penggunaan secara lisan maupun tulisan, sehingga dengan adanya akronim tersebut menjadi lebih hemat, dan apabila istilah tersebut tidak digunakan, maka akan membutuhkan ruang yang lebih dalam surat kabar itu sendiri, mengingat ruang dalam surat kabar terbatas. Namun, istilah abreviasi jenis akronim seperti Jamkesmas tersebut dapat membuat orang menjadi bingung, khususnya bagi pembaca yang masih dikategorikan sebagai remaja. Hal itu disebabkan istilah abreviasi tersebut kadangkala hanya mencantumkan istilahnya saja, tanpa mancantumkan arti yang sebenarnya, sehingga yang pada awalnya surat kabar tersebut menjadi media informasi, justru menjadikan sebagian dari pembacanya kurang memahami apa informasi yang disampaikan oleh surat kabar tersebut.

(2) Kemendagri (A2)

Akronim merupakan suatu proses pemendekan kata yang berupa gabungan huruf awal gabungan suku kata atau pun gabungan huruf dan suku kata dari deret kata yang diperlakukan sebagai kata (Ernawati Waridah, 2008: 15). Berdasarkan data di atas, maka data (2) merupakan abreviasi jenis akronim. Proses terbentuknya kata 
Kemendagri yaitu dikarenakan adanya pengekalan lima huruf pertama pada komponen pertama. Pengekalan dua huruf pertama komponen kedua, dan pengekalan tiga huruf pertama komponen ketiga. Sehingga kata Kemen dikekalkan dari kata Kementrian, dan dikekalkan dari kata dalam dan gri dikekalkan dari kata negeri.

Kemendagri merupakan Kementrian dalam pemerintah Indonesia yang membidangi atau mengurus suatu urusan dalam negeri dan membantu presiden dalam menyelenggarakan pemerintahan negara. Kementrian dalam negeri dipimpin oleh seorang menteri dalam negeri yang ditetapkan langsung oleh presiden.

Sesuai dengan teori yang dikemukakan Waridah, peneliti setuju dengan teori yang digunakan. Hal itu disebabkan akronim merupakan suatu bentuk kependekan dari gabungan huruf yang menjadi suatu kata yang dapat diejakan. Alasan penggunaan istilah abreviasi jenis akronim tersebut dikarenakan lebih efektif, baik dalam penggunaan secara lisan maupun tulisan, karena jika tidak ada pengakroniman seperti itu akan membuat suatu kata menjadi sangat panjang dan kurang efektif, sehingga dengan adanya akronim tersebut menjadi lebih hemat, dan apabila istilah tersebut tidak digunakan, maka akan membutuhkan ruang yang lebih dalam surat kabar itu sendiri, mengingat ruang dalam surat kabar terbatas.

c) Penggalan

\section{(1) Pak(P1)}

Menurut Kridalaksana (2009, hal 172) menyatakan bahwa penggalan merupakan proses pemendekan kata dari kata dasar. Penggalan biasanya ditemukan dalam situasi formal maupun non informal dalam ucapannya, tetapi jarang dituliskan dalam tulisan berita pada surat kabar.

Berdasarkan data di atas, maka data (1) merupakan abreviasi jenis penggalan. Proses terbentuknya kata Pak yaitu dikarenakan adanya pengekalan suku terakhir suatu kata, yaitu pengekalan suku kata Pak dari komponen Bapak. Kata Pak merupakan sapaan pada seseorang yang dianggap dewasa. Kata ini sering digunakan oleh masyarakat, seperti dalam lingkup keluarga. Lingkup ini tentunya ada seorang kepala keluarga (Bapak) dalam suatu rumah tersebut. Biasanya seorang anak maupun istri dari kepala keluarga (Bapak) tersebut memanggil kepala keluarga tersebut dengan sapaan Pak saat ingin memanggilnya. Bagitu pula di dalam lingkup masyarakat juga terdapat banyak fenomena kata sapaan Pak seperti saat bertemu dengan orang yang lebih tua dan menyapa langsung.

Sesuai dengan teori dari Kridalaksana, maka peneliti setuju dengan apa yang telah dikemukakan oleh tokoh tersebut. Hal itu disebabkan penggalan merupakan suatu bentuk pemendekan yang diambil dari kata dasar atau kata asli dalam kaidah bahasa Indonesia, sehingga teori yang digunakan oleh Kridalaksana sejalan dengan pendapat peneliti. Alasan penggunaan istilah abreviasi tersebut dikarenakan lebih efektif, baik dalam penggunaan secara lisan maupun tulisan. Istilah Pak tersebut umum digunakan oleh sebagian orang ketika memanggil seseorang yang telah dianggap dewasa sebagai bentuk kata lain dari nama orang tersebut, sehingga dengan adanya panggilan tersebut tersebut menjadi lebih santun. Hal itu dikarenakan, istilah Pak dirasa lebih efektif dan lebih mudah diingat, serta dalam penggunaannya lebih pas. Sehingga tidak heran istilah tersebut sering dijumpai di berbagai situasi dan kondisi dalam suatu lingkup masyarakat.

d) Kontraksi

(1) Kahutla (K1)

Menurut Mulyono (2013, hal 148) menyatakan bahwa kontraksi adalah pemendekan yang meringkaskan leksem atau gabungan leksem yang dilafalkan seperti sebuah kata yang memenuhi kaidah fonologis. Berdasarkan data di atas, maka data (1) merupakan abreviasi jenis kontraksi. Proses terbentuknya kata Kahutla yaitu dikarenakan adanya pengekalan huruf pertama dan huruf ketiga komponen pertama, tiga huruf pertama komponen kedua dan dua huruf pertama komponen pertama. Kata Ka dari komponen Kebakaran, hut dari komponen hutan, dan la dari komponen lahan.

Kahutla merupakan istilah kependekan dari kata aslinya yakni kebakaran hutan dan lahan. Kahutla yang dimaksud disini yakni adanya suatu peristiwa kebakaran yang melanda hutan maupun lahan pada suatu wilayah. Konteksnya disini yakni kebakaran yang sudah menyebar luas dan api yang mulai membesar. Sehingga dapat dikatakan sebagai kebakaran hutan dan lahan atau Kahutla.

Sesuai dengan teori yang dikemukakan oleh Mulyono, peneliti setuju dengan teori tersebut dan memberi pengertian bahwa kontraksi merupakan suatu bentuk pemendekan dengan cara meringkaskan leksem atau gabungan dari leksem yang kemudian dilafalkan seperti sebuah kata. Alasan penggunaan istilah abreviasi jenis kontraksi tersebut dikarenakan lebih efektif, baik dalam penggunaan secara lisan maupun tulisan,sehingga dengan adanya kontraksi tersebut menjadi lebih hemat kata, dan apabila istilah tersebut tidak digunakan, maka akan membutuhkan ruang yang lebih dalam surat kabar itu sendiri, mengingat ruang dalam surat kabar terbatas. Namun, kontraksi jarang digunakan baik dalam ragam bahasa lisan maupun tulisan, khususnya surat kabar. Hal itu dikarenakan bentuk kependekan dari kontraksi ini 
dapat dikatakan tidak lazim, karena adanya tumpang tindih fonem pada setiap kata, sehingga dirasa seperti kata yang tidak baku dalam kaidah bahasa Indonesia.

d) Lambang Huruf

Lambang huruf yang paling menonjol ditemukan pada terbitan 20 Oktober 2018 terdapat pada lambang huruf yang menyatakan bilangan karena tulisan pada berita banyak mengidentifikasikan dari suatu kelas sosial atau data yang menunjukan hitungan tahun atau bulan, sedangkan data yang ditemukan paling sedikit terdapat pada lambang huruf yang menandai ukuran. Adapun beberapa data yang ditemukan antara lain.

(1) $\mathrm{Kg}(\mathrm{LH} 1)$

Menurut Mulyono (2013, hal 148) memberi pengertian bahwa lambang huruf adalah proses pemendekan kata dari satu huruf atau lebih yang menggambarkan konsep dasar dari satuan kuantitas atau unsur. Berdasarkan data di atas, maka data (1) merupakan abreviasi jenis lambang huruf. Proses terbentuknya kata kg yaitu dikarenakan adanya pengekalan huruf pertama dari komponen gabungan, kg terdiri dari dua komponen, yaitu komponen kilo dan gram.

Istilah $\mathrm{Kg}$ merupakan satuan unit SI untuk massa. Istilah tersebut digunakan untuk mengetahui berat suatu benda dengan cara menimbang. Sehingga hasil akhirnya akan diketahui berapa $\mathrm{Kg}$ berat suatu benda tersebut.

Sesuai dengan teori yang dikemukakan oleh Mulyono, peneliti setuju dan memberi pengertian bahwa lambang huruf merupakan pemendekan yang menghasilkan satui huruf atau lebih yang berkaitan dengan satuan unsur. Istilah tersebut dapat memudahkan penggunanya, pasalnya istilah tersebut juga sudah masuk ke dalam satuan lambang berat. Namun, pengguna atau pembaca istilah tersebut juga harus memerhatikan maksud dari istilah itu sendiri, hal itu dikarenakan agar paham dengan apa yang disampaikan oleh penulis. Istilah tersebut biasanya digunakan dalam lingkup masyarakat saat membeli barang atau benda dengan ukuran berat tertentu sesuai yang diinginkan oleh pembeli atau masyarakat tersebut.

\section{SIMPULAN}

Berdasarkan hasil penelitian dan analisis data pembahasan mengenai abreviasi dalam surat kabar Jawa Pos terbitan terbitan 20 Oktober 2018, dapat disimpulkan sebagai berikut. Bentuka breviasi merupakan bentuk pemendekan yang paling banyak ditemukan digunakan dalam bahasa di surat kabar Jawa Pos. Adapun rincian nya adalah: pertama, bentuk abreviasi yang ditemukan dalam surat kabar Jawa Pos terbitan terbitan 20 Oktober 2018 ditemukan lima jenis, antara lain yaitu singkatan ditemukan sebanyak 24 data. Akronim ditemukan sebanyak 14 data, penggalan ditemukan sebanyak 3 data. Kontraksi ditemukan sebanyak 2 data dan lambang huruf ditemukan sebanyak 5 data. Dengan demikian, singkatan merupakan bentuk abreviasi yang paling banyak ditemukan dalam surat kabar Jawa Pos terbitan terbitan 20 Oktober 2018. Sedangkan yang paling sedikit ditemukan yakni pada bentuk kontraksi.

\section{DAFTAR RUJUKAN}

Azmi, dkk. (2018). Pembentukan Abreviasi Dalam Surat Kabar Padang Ekspres. Jurnal Bahasa dan Sastra: FBS Universitas Negeri Padang.

Budyatna, M. (2009). Jurnalistik: Teori dan Praktik. Bandung: Remaja Rosdakarya.

Chaer, A. (2006). Tata Bahasa Praktis Bahasa Indonesia. Jakarta: Rineka Cipta.

Djuroto. T. (2002). Menulis Artikel dan Karya IImiah. Bandung: Remaja Rosdakarya.

Mulyono, I. (2013). Morfologi (Teori Sejumput dan Problematik Terapannya). Bandung: Yrama Widya.

Sudaryanto. 2015. Metode dan Aneka Teknik Analisis Bahasa. Yogyakarta: Sanata Dharma University Press.

Sukmadinata, Nana Syaodih. (2013). Metode Penelitian Pendidikan. Bandung: Rosdakarya.

Sumadiria A.S.H. (2005). Jurnalistik Indonesia: Menulis Berita dan Feature. Bandung: Remaja Rosdakarya.

Waridah, Ernawati. (2008). EYD \& Seputar Kebahasa-Indonesiaan. Jakarta: Kawan Pustaka. 